\title{
POLYELECTROLYTE MULTILAYER TEMPLATE ASSISTED IN-SITU SYNTHESIS OF THE INORGANIC NANOSTRUCTURES
}

\author{
M. Logar, ${ }^{1 *}$ B. Jančar, ${ }^{1}$ A. Rečnik ${ }^{2}$, D. Suvorov ${ }^{1}$ \\ ${ }^{1}$ Advanced Materials Department, Jozef Stefan Institute, \\ Jamova 39, 1000 Ljubljana, Slovenia \\ ${ }^{2}$ Nanostructured Materials Department, Jozef Stefan Institute, \\ Jamova 39, 1000 Ljubljana, Slovenia
}

\begin{abstract}
Apstract: Multilayers formed from weak polyions of polyallylamine (PAH) and polyacrylic acid (PAA), possessing ion-exchangeable carboxylic groups were used to bind the metal cations within the film. By subsequent wet chemical reaction process of the incorporated metal ions, pure zinc sulfide $(\mathrm{ZnS})$ with a narrow size distribution was formed within the PEMs. The size and concentration of the inorganic nanoparticles in polyion matrix were controlled by the concentration of metal - binding carboxylic acid groups as determined by the multilayer assembly $\mathrm{pH}$. Furthermore, the metal cation loading and reaction methodology could be repeatedly cycled to increase the size and volume density of the nanoparticles. Furthermore, the polyelectrolyte multilayer films were used as templates for the ceramic $\left(\mathrm{TiO}_{2}\right)$ thin film fabrication with a modified sol-gel reaction. Since the multilayer assembly is performed from the polyion aqueous solutions, the multilayers contain some water that, after infiltration of the organometallic precursor, enables in-situ reaction of hydrolysis and condensation reaction. After calcination, nanocrystalline $\mathrm{TiO}_{2}$ thin films with thickness, controllable by the number of the polyion layers in the matrix, were formed. With the in-situ synthesis approach of inorganic nanstructures in polyelectrolyte multilayer matrix, the ability of obtaining the control over the film thickness and size of the inorganic particles has enabled the tuning of the optical properties of as fabricated inorganic-organic composite films, as well as nanocrystalline ceramic films.
\end{abstract}

Keywords: Polyelectrolyte multilayer, in-situ synthesis, $\mathrm{ZnS}$ nanoparticles, Nanocrystalline $\mathrm{TiO}_{2}$ film.

\section{INTRODUCTION}

Thin film nanocomposites consisting of inorganic matter embedded within a soft polymeric matrix on the nanometer scale offer unique properties with potential application in the optoelectronics and photonics. Inorganic nano-sized particles have been investigated intensely due to their potentially interesting optical properties, steaming from the quantum confinement effect and their surface characteristics. By approaching to the nano-meter regime, due to the size dependency of the particle band gap energy and increase in the surface-to-volume ratio, a careful control over the size and surface state density of the inorganic particles is essential in order to obtain the desired physical properties [1]. By embedding the inorganic nanoparticles within a suitable matrix, possible control over the particle surface states and si- ze-distribution yield the ability to control their physical properties thus making such inorganic-organic nanostructured materials more attractive for their potential application in different areas [2-3].

Recently, organized supramolecular assemblies, formed by the layer-by-layer (LbL) self-assembly of polyelectrolytes, have been extensively utilized as organic nanostructured templates for the inorganicorganic nanocomposite film formation [4]. With this method, the sequential adsorption of oppositely charged polyelectrolytes, based on the electrostatic interactions between the two components, yield the multilayer network structure, where, by varying the number of the adsorbed polyion layers, the control over its thickness in nanometer scale is obtained. In the assembly of the polyion chains, their molecular organizations lead to the formation of voids within the multilayer template, which can serve as sites for 
the in-situ nucleation and growth of the inorganic particles.

Most of the literature reports on the use of strong polyions as nanoreactors for the nucleation and growth of semiconductor nanoparticles [5-6]. The main disadvantage in the use of strong polyions is the absence of ability to control the volume density and size distribution of the inorganic species within the polyelectrolyte multilayers (PEMs). In contrast, by utilization of weak polyion assemblies, better control over the volume density of the in-situ synthesized inorganic nanoparticles in polyion matrix is possible, by means of controlling the degree of ionization of the acid groups in the multilayer film with the $\mathrm{pH}$-value of the PE assembly. Metal ions are able to coordinate to the free carboxylic groups by an ion-exchange with the acid protons and the volume density of the inorganic particles in the matrix, after the post-binding precipitation reaction, thus depending on the portion of the available acid groups in the polyion multilayer film [7-8]. In this study the growth characteristics of the zinc sulfide $(\mathrm{ZnS})$ nanocrystals in organized supramolecular thin films formed by weak polyion, polyacryllic acid (PAA) and polyallylamine (PAH), layer by layer (LbL) self-assembly method. As the physical properties of semiconducting nanoparticles are affected by their size, morphology and crystal structure, we investigated the growth characteristics of the $\mathrm{ZnS}$ nanocrystallites within the weak PEM assemblies and correlated these to the optical properties of $\mathrm{ZnS} /$ PEM composite films.

Due to their versatility with regard to applications in dye-sensitized solar cells [9], gas sensors [10], and photocatalysts [11] nanocrystalline inorganic titanium dioxide $\left(\mathrm{TiO}_{2}\right)$ films have recently attracted much attention. Due to the high transparency of $\mathrm{TiO}_{2}$ in the visible and near-infrared regions of the electromagnetic spectrum (ES), $\mathrm{TiO}_{2}$ films can be used as anti-reflection coatings for increasing the visible transmittance in a heat mirror, while the high absorption of UV light, due to high photo-activity of $\mathrm{TiO}_{2}$, leads to applications in solar-energy conversion [12]. Several methods have been used for the preparation of $\mathrm{TiO}_{2}$ thin films, such as chemical vapor deposition [13], chemical spray pyrolysis [14], pulsed-laser deposition [15] and the sol-gel method [16]. However, rather than vacuum-based processing, wet chemical methods are preferable for ultrathin films, because of the low processing temperatures and the moderate pressures. The sol-gel process is very promising because the crystallite size, the morphology and the porosity can be controlled by adjusting the synthesis parameters [17]. Nevertheless, with the conventional sol-gel method, control over the film thickness and the crystallite size on the nanometer scale is still limited [18-19].

Among organic matrices, polyelectrolyte multilayers (PEMs) composed of strong polyions have been used as templates for sol-gel reactions in the fabrication of composite, $\mathrm{TiO}_{2}$ core-shell colloids and hollow spheres [20-22]. Since the polyelectrolytes are deposited from aqueous solutions, water is absorbed in the PEM, which serves to localize the reactions of the sol-gel process within the organic template as the template is exposed to the anhydrous sol-gel precursor solution [20]. With the ability to control the thickness of the PEM by the number of adsorbed PE layers, the PEM, template-assisted, insitu, sol-gel reaction makes possible the formation of core-shell colloids with a precise control over the shell thickness. In this study, we extended the mechanism of the in-situ, sol-gel reaction within the PEM template to the fabrication of crystalline $\mathrm{TiO}_{2}$ thin films on flat substrates. The PEM template was formed by using the Layer-by-Layer (LbL) self-assembly of weak polyelectrolytes, polyacryclic acid (PAA) and polyallylamine (PAH). Since the assembly was performed from solutions at a $\mathrm{pH}$-value that is lower than the $\mathrm{pKa}$ value of the polyanion (PAA), non-ionized carboxylic acid moieties of the PAA chains in the PEM template could moderate the reactivity of the titanium precursor with water in the PEM thus allowing the control over the crystallite size in the final film. As the physical properties of semiconducting nanocrystals are affected by their size, morphology and crystal structure, the optical properties of the crystalline $\mathrm{TiO}_{2}$ films were investigated.

\section{EXPERIMENTAL}

The PEMs of PAH and PAA were assembled on the polystyrene (PS) tissue-culture substrates (corona-treated Nalge Nunc International, Naperville, IL) and quartz wafers (Si-Mat, Germany) using a dipping procedure. Prior to the PEM assembly, the quartz slides were treated with the Piranha solution $\left(\mathrm{H}_{2} \mathrm{O}_{2} / \mathrm{H}_{2} \mathrm{SO}_{4}=30: 70 \mathrm{v} / \mathrm{v} \%\right)$ and subsequently thoroughly washed in deionized water. The Piranha-solution treatment removes all traces of the organic materials sticking to the quartz surface in addition to making the surface hydrophilic, as described in detail further on [14]. The PS substrates were used asreceived, whereas the PAH and PAA dipping solutions were adjusted to the desired $\mathrm{pH}( \pm 0.1)$ using either $1 \mathrm{M} \mathrm{HCl}$ or $1 \mathrm{M} \mathrm{NaOH}$.

The PEMs were formed by immersing the substrates into the PAH solution $\left(10^{-2} \mathrm{M}\right.$ by repeat unit) for $10 \mathrm{~min}$, followed by two 1-min immersions 
into the water, as rinsing steps. The substrates were then immersed into the PAA solution $\left(10^{-2} \mathrm{M}\right)$ for 10 min, followed by identical rinsing steps. The adsorption and the rinsing steps were repeated until the desired thickness of polyelectrolyte multilayer was obtained.

$\mathrm{ZnS}$ nanoparticles were synthesized in-situ in a 7.5 PAH/PAA bilayered polyion multilayer matrix fabricated by the LbL self-assembly of oppositely charged PAA and PAH weak polyions at the $\mathrm{pH}$ values of 2.5 and 3.0, respectively. To increase the ion binding efficiency in the PEMs polyion film was first exposed to the $0.001 \mathrm{M} \mathrm{NaCl}$ solution which converts the carboxylic acid groups to the sodium carboxylate form [15]. For the in-situ ZnS nanoparticle synthesis, PEMs with 7.5 bilayers of $\mathrm{PAH} /$ PAA, assembled at $\mathrm{pH}$ values of 2.5 and 3.0, were immersed in an aqueous solution of $\mathrm{Zn}$-acetate $(0.01$ $\mathrm{M})$ at the $\mathrm{pH}$ value of 5.5 for 24 hours. After the ion exchange the films were rinsed in deionized water and dried in vacuum. The subsequent precipitation of the $\mathrm{ZnS}$ nanoparticles in PEM is performed by exposing the $\mathrm{Zn}$ ion-containing films to the $0.02 \mathrm{M}$ $\mathrm{Na}_{2} \mathrm{~S}$ aqueous solution for 1 hour. The number of the reaction cycles $(n)$ in the $\mathrm{ZnS}$ nanoparticle synthesis, comprising of the metal cation binding to the ionized carboxylic groups of the PAA and subsequent sulfidization of incorporated $\mathrm{Zn}^{2+}$ ions, were varied from $n=1$ to $n=3$.

For the crystalline $\mathrm{TiO}_{2}$ filmPEM templates with 7, 12 and $17 \mathrm{PE}$ bilayers were formed, where one bilayer of the PEM is defined as a single adsorption of polycation (PAH), followed by an adsorption of the polyanion (PAA). The sol-gel precursor solution was prepared by dissolving titanium iso-propoxide (Sigma-Aldrich) in iso-propanol in the volume ratio 1:10. Prior to the exposure of the PEM template to the sol-gel precursor solution, the templates were dried under the ambient conditions for $0.5 \mathrm{~h}$, which resulted in the formation of a water gradient in the PEM template [24]. The templates were then exposed to the anhydrous titanium iso-propoxide precursor solution in an inert (Ar) atmosphere for 15 min, causing it to infiltrate the multilayer film. To achieve a high degree of infiltration of the multilayer template, the process of infiltration/solidification of the precursor was repeated five times, with washing in anhydrous iso-propanol between the each step. Finally, the samples were dried under the ambient conditions. The crystalline $\mathrm{TiO}_{2}$ film was obtained by subsequent removal of the organic template; this involved calcination of the samples at $500^{\circ} \mathrm{C}$ $\left(2{ }^{\circ} \mathrm{C} / \mathrm{min}\right)$ for $1 \mathrm{~h}$ in air.

The film thicknesses were measured using profilometry (Form Talysurf Series 2, Taylor-Hobson
Ltd, Leicester, UK). The films were scratched with a razor blade to form the lines. By profiling the scored line prior to, and after the calcination process, the film thicknesses were measured. An average value of five measurements was chosen to represent the thickness of the film. The contraction in the film thicknesses was calculated from the film-thickness measurements before and after the calcination process.

\subsection{Characterization}

For transmission electron microscopy (TEM) observations, the polyion films with $\mathrm{ZnS}$ nanoparticles on a polystyrene (PS) tissue-culture substrates were cut using a ultramicrotome (Reichart Ultracut $\mathrm{S}$, Leica) with a $45^{\circ}$ diamond knife (Diatome, Fort Washington, PA). Approximately $50 \mathrm{~nm}$ thick sample cross-sections were then deposited on the lacey carbon TEM grid. The TEM studies were performed by using a $200 \mathrm{kV}$ TEM (JEM-2100 HR, Jeol Inc., Tokyo, Japan). For high-resolution TEM and electron diffraction studies the $\mathrm{ZnS}$ nanoparticles were ultrasonically separated from the polymer matrix. Both the selected area electron diffraction (SAED) on multiple $\mathrm{ZnS}$ particles and the electron micro-diffraction on oriented single $\mathrm{ZnS}$ particles were used to determine the structural characteristics of $\mathrm{ZnS}$ nanoparticles formed in the PEM matrix.

From the TEM images, the diameters of $\sim 100$ particles for each sample were measured in order to determine the average particle size.

Optical spectra of the composite films deposited on quartz substrates were measured using a UVvis transmission spectrophotometer (Hewlett-Packard -8453) while the emission properties of the composite films were measured by fluorescence spectroscope (Hitachi, F-4500 FL spectrophoto-meter). The room temperature photoluminescence emission spectra of the $\mathrm{ZnS}$ composite films were recorded with an excitation wavelength of $270 \mathrm{~nm}$ under the identical conditions.

The surface morphology of the $\mathrm{TiO}_{2}$ films on the silicon substrates was examined by using a fieldemission scanning electron microscope (FE-SEM, SUPRA 35VP,Carl Zeiss, Oberkochen, Germany) and an atomic force microscope (AFM - Veeco DI 3100, Nanoscope 4, CA) in the tapping mode. FESEM and TEM (TEM, Jeol, JEM 2100, Tokyo, Japan) imaging were used to evaluate the crystallite size. The crystalline phase of the $\mathrm{TiO}_{2}$ films was determined by an X-ray diffractometer (PANalytical X'Pert PRO - $\mathrm{CuK} \alpha=1.5406 \AA$ ) and selected-area electron diffraction (SAED). The optical spectroscopy measurements of the films on quartz substrates were performed by using a UV-vis transmission 
spectrophotometer (Hewlett-Packard 8453, Palo A1to, $\mathrm{CA})$.

\section{RESULTS AND DISCUSSION}

\subsection{In-situ synthesis of semiconducting ( $\mathrm{ZnS})$ nanoparticles in PEMs}

The zinc sulfide $(\mathrm{ZnS})$ nanoparticles were synthesized in situ in 7.5 bilayered PEM matrixes. To obtain the control over the volume fraction and over the size of the $\mathrm{ZnS}$ particles in the composite film, the matrix was assembled at the $\mathrm{pH}$ value of 2.5 and 3.0, respectively. The reaction cycle comprised of the zinc ion binding to the ionized groups of the polycation (PAA) followed by subsequent sulfidation of the ions incorporated in the matrix was varied from $n=1$ to $n=3$.

\subsubsection{Growth characteristics of $\mathrm{ZnS}$ nanoparticles in PEMs assembled at different $\mathrm{pH}$ values}

The cross-sectional TEM images of the $\mathrm{ZnS} / \mathrm{PEM}$ composite films fabricated during the PEM assembly at $\mathrm{pH}$ values of 2.5 and 3.0 (Figure 1) indicate that the size of the in-situ synthesized $\mathrm{ZnS}$ particles is in the range of a few nanometers. The $\mathrm{ZnS}$ nanoparticles in the PEM are spherical and evenly distributed within the polyion multilayer films.
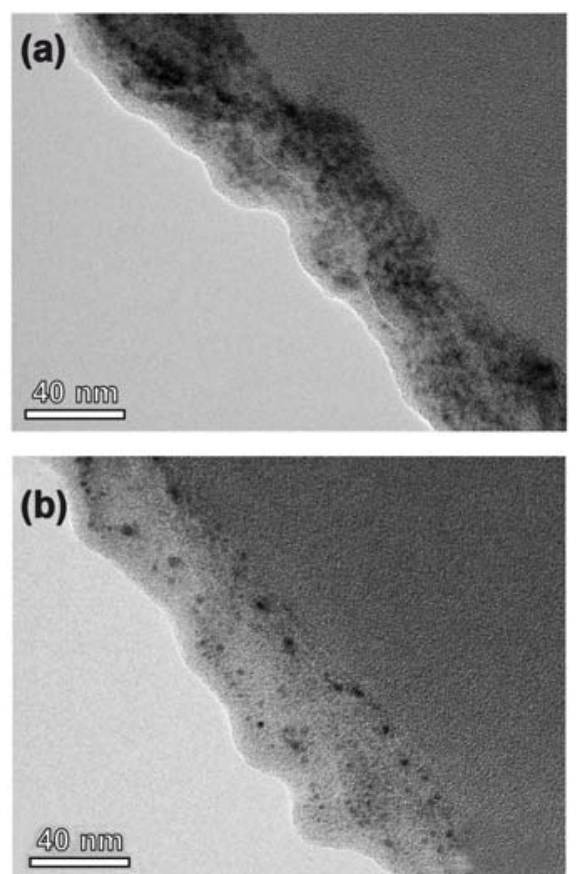

Figure 1. Cross-sectional bright-field TEM images of $\mathrm{ZnS}$ nanoparticles synthesized in-situ in PEMs assembled at a) $p H=2.5$ and $b) p H=3$.
By increasing the $\mathrm{pH}$ value of the PEM assembly from 2.5 to 3.0 a lower volume density of $\mathrm{ZnS}$ nanoparticles within the multilayer film is observed, together with a reduced thickness of the pristine matrix assembled at the lower $\mathrm{pH}$. After the $\mathrm{ZnS}$ nanoparticle precipitation, from the increase in the film thickness, calculated volume fractions of $\mathrm{ZnS}$ of $30 \%$ and $16 \%$ were obtained in the polyion matrixes assembled at $\mathrm{pH}$ values of 2.5 and 3.0, respectively. The explanation for different volume fraction of $\mathrm{ZnS}$ nanoparticles in PEM is the same as in the case of the in-situ synthesized Ag nanoparticles in PEMs assembled at different $\mathrm{pH}$ values. The PEM template assembled at the lower $\mathrm{pH}$ value allows more $\mathrm{Zn}$ ions to coordinate along the PAA chains, as the template is exposed to the $\mathrm{Zn}$-ion solution at the $\mathrm{pH}$ value of 5.5, at which point the PAA chains become fully ionized. As a result, after sulfidation of the adsorbed $\mathrm{Zn}$ ions, a higher volume density of the $\mathrm{ZnS}$ nanoparticles in the polyionic film assembled at the $\mathrm{pH}$ value of 2.5 , compared to that at $\mathrm{pH}=3.0$, was obtained, as is clear from Figure 1 .

Due to the coordination of the $\mathrm{Zn}$ ions with the carboxylate groups of the PAA chains, after the sulfidation reaction, their growth is restricted within specific regions of the matrix by the surrounding polyion chains. Moreover, the electrostatic forces within the matrix hinder the particle aggregation thus enabling the $\mathrm{ZnS}$ particles to be well dispersed within the PEM film. The average $\mathrm{ZnS}$ particle diameters were $3.2 \pm 0.2 \mathrm{~nm}$ and $3.6 \pm 0.4 \mathrm{~nm}$ in the polyion matrixes assembled at $\mathrm{pH}$ values of 2.5 and 3.0 , respectively.

In the weak PEM assembly, a high interpenetration of the oppositely charged PE chains yielded a dense polyion matrix within which small cavities may exist [23]. Consequently, small $\mathrm{ZnS}$ nanoparticles were formed within the multilayer matrix. The $\mathrm{ZnS}$ nanoparticles nucleated within the polymer cavities continued to grow until steric stabilization of the nanoparticles was obtained. Since the cavity walls physically restrict the particle growth, the morphology and the size of the $\mathrm{ZnS}$ crystallites can be attributed to the morphology of the void spaces induced by the $\mathrm{pH}$-value-determined molecular organization of the polyion chains in the PEM assembly. Regardless of the $\mathrm{pH}$ of the multilayer assembly, the shape of the synthesized $\mathrm{ZnS}$ crystallites was spherical, which may indicate the formation of spherical voids within the polymer network fabricated by the LbL self-assembly of the weak polyions.

Figure 2 shows the $\mathrm{ZnS}$ nanoparticles formed in the matrixes assembled at $\mathrm{pH}$ values of 2.5 and 3.0. 


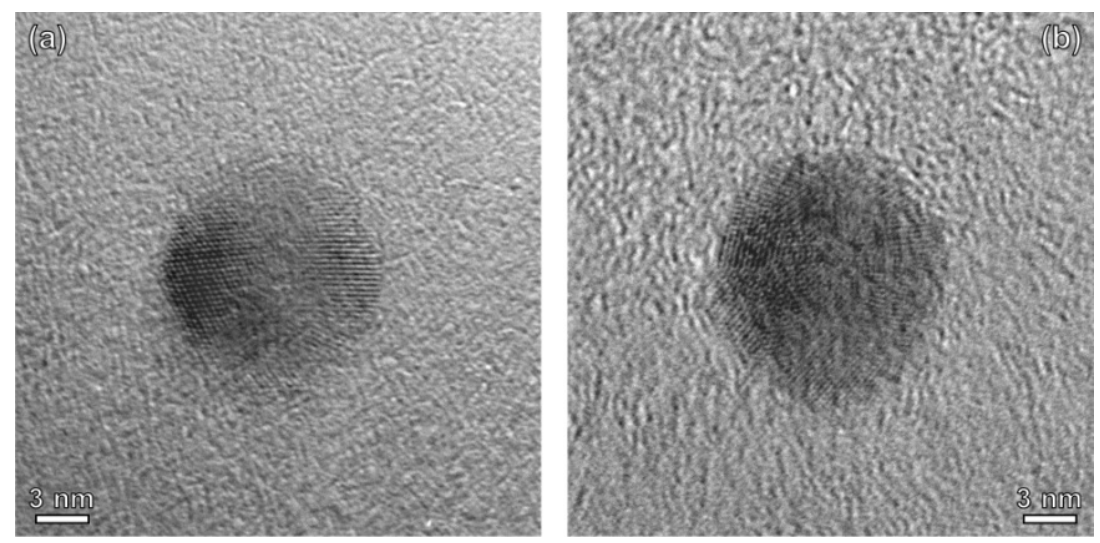

Figure 2. Lattice images of nanosized ZnS crystal clusters formed in polyion matrix assembled at the a) $\mathrm{pH}=2.5$ and b) $\mathrm{pH}=3.0$.

The morphology of the $\mathrm{ZnS}$ nanoparticles suggests that the as-formed $\mathrm{ZnS}$ clusters are constructed of more primary building particles of different orientations. In order to reduce the high surface energy, the primary particles of $2-3 \mathrm{~nm}$ in diameter, tend to assemble into larger clusters by a random-aggregation mechanism. The aggregation of the nanoparticles is even more likely to occur at a $\mathrm{pH}$ value close to the iso-electric point of the $\mathrm{ZnS}$ crystal surfaces, as the net charge of the particle double layer is decreased. Since precipitation of the $\mathrm{ZnS}$ crystallites within the polyion matrix was performed in a $\mathrm{Na}_{2} \mathrm{~S}$ solution at a $\mathrm{pH}$ value of 5.5 , which is in the range of the average iso-electric point of a $\mathrm{ZnS}$ nanoparticle, the Brownian-motion-driven particle collisions can effectively overcome the surface-repulsive forces resulting in the agglomeration of the primary $\mathrm{ZnS}$ crystallites [24]. Furthermore, as the $\mathrm{pH}$ value of the PEM assembly was increased from 2.5 to 3.0, some larger clusters of primary $\mathrm{ZnS}$ particles were formed in the PEM.

In Figure 3, (a) the $\mathrm{ZnS}$ cluster formed of many primary $\mathrm{ZnS}$ particle and (b) single-crystalline $\mathrm{ZnS}$ nanoparticle after, synthesized in PEM at the assembly pH 3.0 are shown.
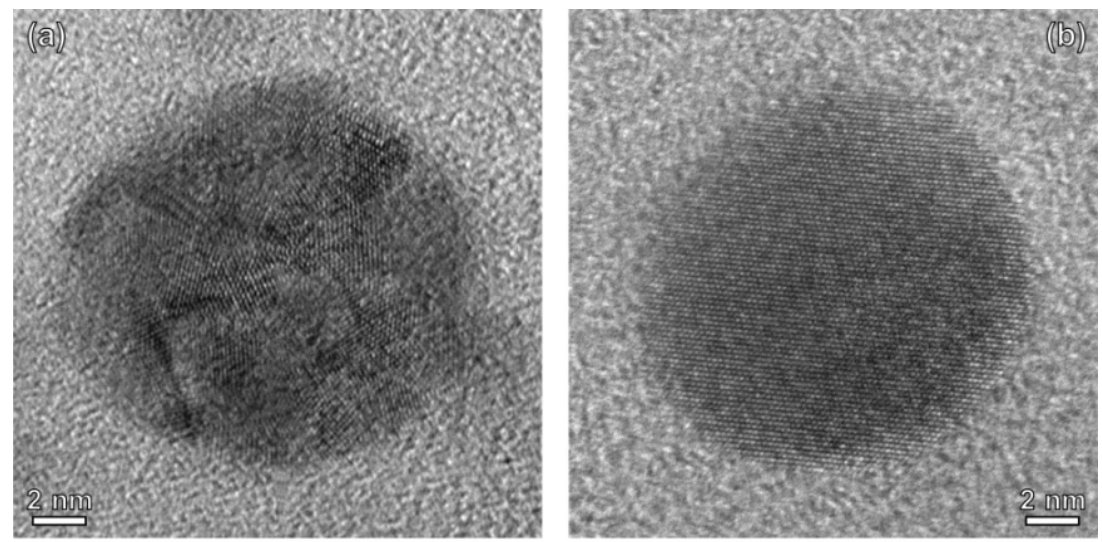

Figure 3. HRTEM images of the ZnS nanocrystallites formed in PEM assembled at $\mathrm{pH}=3.0$ a) polycrystalline $\mathrm{ZnS}$ particle, (b) single-crystalline ZnS particle.

As the PE assembly $\mathrm{pH}$ is increased, the $\mathrm{ZnS}$ clusters within the polyion matrix were formed by aggregation of more primary $\mathrm{ZnS}$ particles. Since the voids in the polyion matrix assembled at higher $\mathrm{pH}$ values of the polyion assembly contained more free carboxylic groups, which exhibited a particlestabilizing effect [25], the aggregation of the primary $\mathrm{ZnS}$ particles in the polyion matrix is more pronounced as the $\mathrm{pH}$ value of the polyion assembly was in- creased to a value of 3.0 (Figure 3). Furthermore, with the increase in the assembly $\mathrm{pH}$, the flatter conformational arrangement of the polyion chains in the multilayer matrix induces larger void spaces within the polymer network, thus the agglomeration of the primary particles is less suppressed as the $\mathrm{pH}$ value of the polyion matrix was increased. Within the clusters, the primary $\mathrm{ZnS}$ particles, aggregated in a random manner, underwent a subsequent recrystalliza- 
tion process, having resulted in single-crystalline particles, as shown in Figure 3.

A high proximity of very small crystallites within the $\mathrm{ZnS}$ aggregates can induce the crystal growth via an oriented-attachment (OA) mechanism [26]. With the cluster formation, primary nanoparticles combine with their high energy interfaces, thereby releasing their free surface energy. According to the OA-based coarsening mechanism, a small distances between the particles, caused by a random aggregation, can ensure jiggling of the nanoparticles as a result of the Brownian motion and induce adjacent surfaces short-range interaction that enables the reorientation of the adjacent particle, in order to adopt the lowest energy conformation represented by the coherent particle-particle interface. In addition to $\mathrm{ZnS}$, an OA-based coarsening mechanism was also reported for $\mathrm{TiO}_{2}, \mathrm{FeOOH}$ and $\mathrm{CoOOH}$ nanocrystallites [27-28], whereas the formation of a coherent interface with $\mathrm{ZnS}$ nanoparticles is even more likely to occur due to the high symmetry of the sphalerite crystal structure [26,29-30]. While the oriented attachment of individual particles normally results in the formation of irregularly-shaped crystallites with abrupt edges, the formation of rounded $\mathrm{ZnS}$ crystallites could be attributed to simultaneous diffusion via surface reorganization, which may eliminate the indents at the particle contacts [27].

\subsubsection{Growth characteristics of $\mathrm{ZnS}$ nanoparticles in PEMs induced by variation in the number of reaction cycles}

By cycling the synthesis process, $\mathrm{ZnS}$ nanoparticles retain their spherical shape and continue to be homogeneously distributed within the composite film as shown in Figure 4(a). The volume density and the size of the $\mathrm{ZnS}$ nanoparticles in the PEM are increased by repeating the ion-loading-precipitation reaction cycle. After the first precipitation cycle, the carboxylic groups are regenerated which enabled further $\mathrm{Zn}$ ion binding within the polyion matrix. As a result, in PEM assembled at $\mathrm{pH}$-value of 2.5 after three reaction cycles, an increase in the volume fraction to $60 \%$ is observed. The size distribution of $\mathrm{ZnS}$ nanoparticles in PEM assembled at $\mathrm{pH} 2.5$ after three reaction cycles is shown in Figure 4(b).
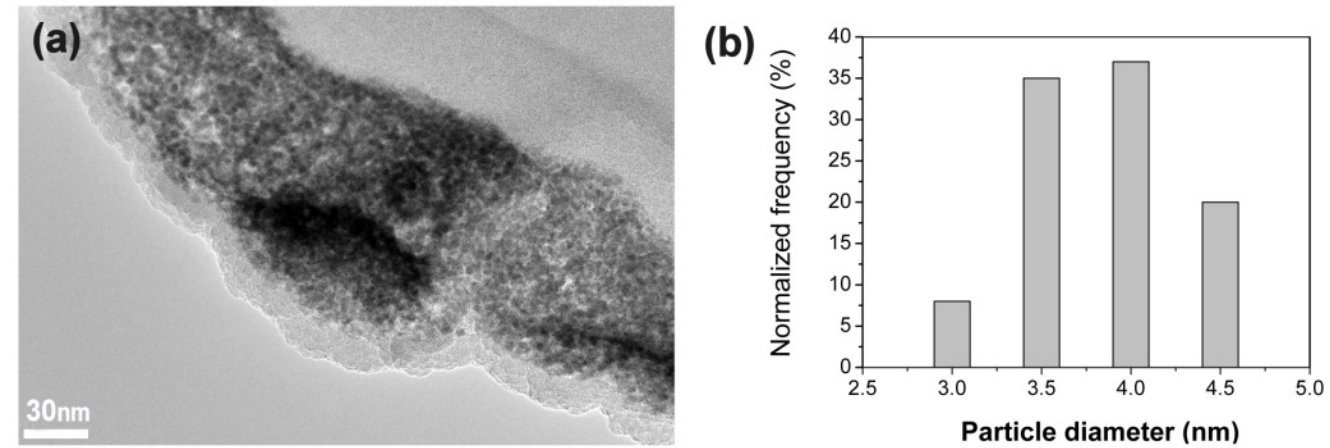

Figure 4. (a) Cross-sectional TEM image of ZnS nanoparticles in PEM assembled at pH 2.5 after three reaction cycles, (b) histogram of the ZnS nanoparticle size distribution.

The average $\mathrm{ZnS}$ particle diameter was increased from $3.2 \pm 0.2 \mathrm{~nm}$ to $3.9 \pm 0.3 \mathrm{~nm}$ after three reaction cycles in the PEM assembled at a $\mathrm{pH} 2.5$. Although the $\mathrm{ZnS}$ nanoparticles synthesized in the PEM were sterically stabilized by the surrounding polymer network, any further metal-cation binding in close proximity to the existing particle after the sulfidation reaction of the $\mathrm{Zn}$ ions favors further particle growth via the Ostwald-ripening mechanism. With the close particle contact, a diffusion-precipitation-based growth occurs and the larger primary par- ticles increase in size, consuming the freshly available constituent material.

For the $\mathrm{ZnS}$ nanoparticles, synthesized in PEMs after three reaction cycles, the SAED pattern (Figure 5(b)) recorded over the area of isolated $\mathrm{ZnS}$ nanocrystallites (Figure 5(a)) indicates the cubic crystal structure of $\mathrm{ZnS}$. The lattice parameter a, calculated from the measured d-spacings, is $5.4 \AA$, which corresponds to the cubic sphalerite $(\beta-\mathrm{ZnS})$ structure. 

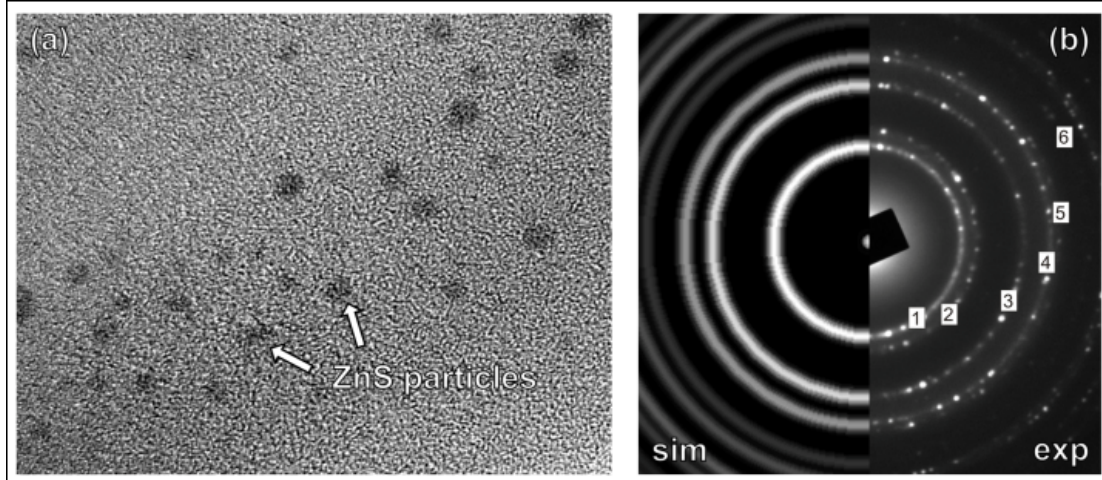

(c)

Figure 5. (a) TEM image of the ZnS nanoparticles after 3 reaction cycles with the (b) corresponding selected area diffraction (SAED) pattern. The numbers on the experimental ringSAED pattern indicate the $\{h k l\}$-planes of $\beta$-ZnS listed in Figure 5(c).

\subsubsection{Optical properties of ZnS/PEMs nanocomposite films}

\subsubsection{Optical absorption studies}

To study the particle size-dependent optical properties, UV-vis absorption measurements of $\mathrm{ZnS}$ nanoparticle/PEM composites were performed. From the optical absorption spectra shown in Figure 6, a prominent absorption peak at wavelength of $260 \mathrm{~nm}$ is obtained for the composite film of $\mathrm{ZnS}$ nanoparticles in polyion matrix assembled at the $\mathrm{pH}$ value of 2.5.

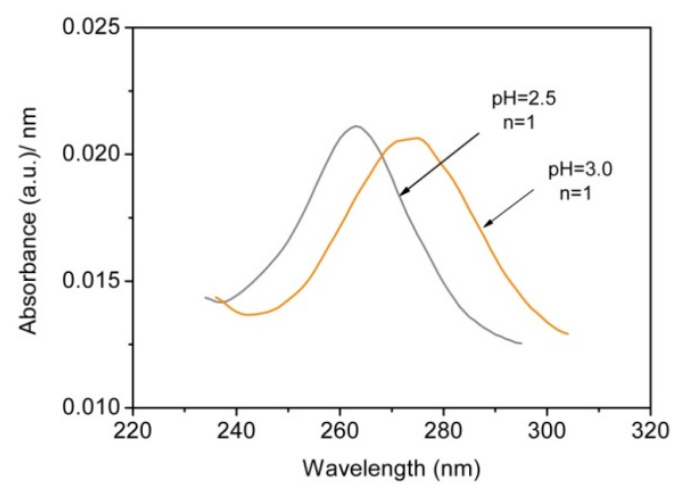

Figure 6. UV-vis absorption spectra for the ZnS nanoparticle/PEM composite films; the $\mathrm{pH}$ value of the polyion matrix assembly is increased from 2.5 to 3.0.

In Figure 7, the red-shift of the absorption maxima position after three reaction cycles is shown. The red-shift of the absorption maxima peak position as the $\mathrm{pH}$-value of the polyion matrix assembly is increased from 2.5 to 3.0 and also after three reaction cycles points to the formation of larger $\mathrm{ZnS}$ crystallites within the polyion matrix which confirms the observation from the TEM images.

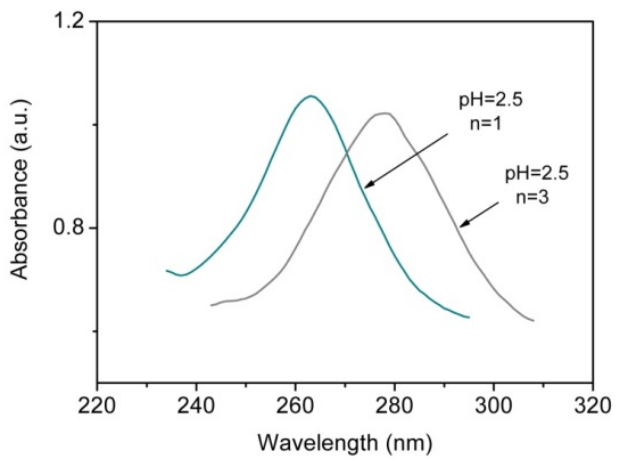

Figure 7. UV-vis absorption spectra for the $\mathrm{ZnS}$ nanoparticle/PEM composite films; the number of the reaction cycles (n) is varied from $n=1$ to $n=3$.

The absorption coefficient $(\alpha)$ is connected to the band-gap energy $\left(\mathrm{E}_{\mathrm{g}}\right)$ by the relation

$$
\alpha=\frac{B\left(h v-E_{g}\right)^{1 / 2}}{h v}
$$

where $B$ is the absorption constant for the allowed direct transition, $\mathrm{h}$ is Planck's constant and $v$ is the photon frequency [31]. By plotting $(\alpha h v)^{2} v s . h v$ and extrapolating the linear portion of the curve to $\alpha=0$, the corresponding band-gap energy $\left(E_{g}\right)$ is obtained.

Based on the effective mass approximation [32], from the obtained band-gap values, the mean particle diameters are estimated according to the equation.

$\Delta E=E_{g(\text { nano })}-E_{g(\text { bulk })}=\frac{h^{2}}{8 r}\left(\frac{1}{m_{e}^{*}}+\frac{1}{m_{h}^{*}}\right)-\frac{1.8 e^{2}}{4 \pi \varepsilon \varepsilon_{0} r}$

The band-gap values and the corresponding values of the average particle diameters are shown in Table 1. 
Table 1. Band gap energies (Eg) and corresponding average $\mathrm{ZnS}$ particle diameter values ( $\mathrm{nm}$ )

\begin{tabular}{|c|c|c|}
\hline $\begin{array}{c}\mathrm{pH} \text { of PEM } \\
\text { assembly/number } \\
\text { of the reaction } \\
\text { cycles }(\mathrm{n}\end{array}$ & $\begin{array}{c}\text { Band gap } \\
\text { energy } \\
(\mathrm{Eg}) \\
{[\mathrm{eV}]}\end{array}$ & $\begin{array}{c}\text { Calculated } \\
\text { mean } \mathrm{ZnS} \\
\text { particle } \\
\text { diameter } \\
(\mathrm{nm})\end{array}$ \\
\hline $2.5 / \mathrm{n}=1$ & 4.33 & 2.8 \\
\hline $2.5 / \mathrm{n}=3$ & 4.14 & 3.3 \\
\hline $3.0 / \mathrm{n}=1$ & 4.09 & 3.5 \\
\hline
\end{tabular}

The increase in the band gap energy values with respect to the bulk $\mathrm{ZnS}$ ( $E_{g}=3.66 \mathrm{eV}$ ) is consistent with the observations from the TEM images that the size of the $\mathrm{ZnS}$ nanoparticles formed within the polyion matrix is in the nanometer scale, whereas gradual decrease in the band gap energy with the increasing $\mathrm{pH}$-value of the polyion assembly from 2.5 to 3.0 point to the formation of larger $\mathrm{ZnS}$ particles in polyion matrix. Furthermore, a lower band gap energy of the $\mathrm{ZnS}$ crystallites after three reaction cycles reflects the increase in size of the nanoparticles attributed to the dissolution-precipitation growth process. Therefore, by varying the $\mathrm{pH}$-value of the polyion matrix assembly and also by repeating the absorption-precipitation cycle, the control over the size and optical properties of the in-situ synthesized $\mathrm{ZnS}$ nanoparticles in the weak polyion matrix is obtained.

\subsubsection{Photoluminescence studies}

After the excitation, the photoluminescence (PL) spectra of the $\mathrm{ZnS}$ nanocomposite films exhibit an intense UV-peak located at wavelength around $300 \mathrm{~nm}$ along with the blue emission peak located at $420 \mathrm{~nm}$ as shown in the Figure 8.

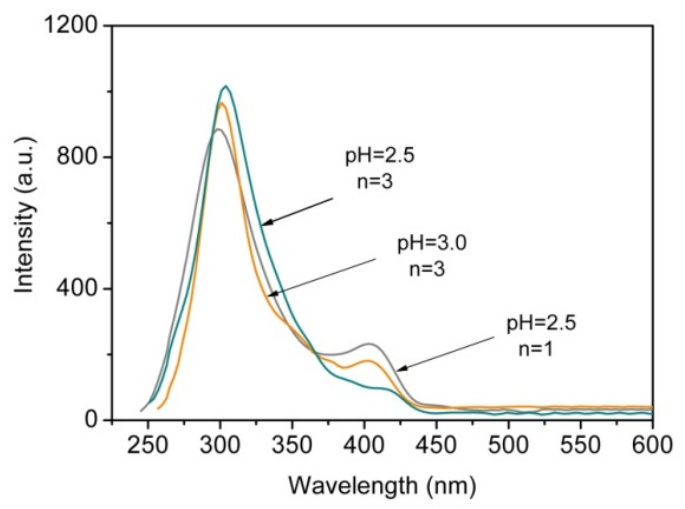

Figure 8. PL spectra of the ZnS nanoparticle in polyion matrix of the ZnS nanoparticle in polyion matrix assembled at the $\mathrm{pH}$-value of $2.5 n=1,3.0 n=1$ and $2.5 n=3$
Regarding the nature of the exciton transitions in the $\mathrm{ZnS}$ nanoparticles, the peak located in the UV region is attributed to the excitonic emission, while the blue emission is induced by the trapped states due to the presence of localized surface defects of the $\mathrm{ZnS}$ nanocrystallites.

Due to the electron-phonon coupling, a slight red-shift of the band gap emission, compared to the absorption maxima wavelength, is observed. From the spectra, it is clear that well defined excitonic emission prevails over the surface state related emission located at $410 \mathrm{~nm}$, which may be attributed to the reduction of surface defects of the $\mathrm{ZnS}$ nanoparticles as the result of their surface passivation by the polyion matrix.

Due to the quantum size effect, the variation in size of the nanoparticles is reflected in the energy value of the band gap. As a result, with the decreasing particle size the blue-shift of the band-edge emission peak wavelength is expected [33]. Therefore, the red-shift of the radiative emission peak with the increase in the $\mathrm{pH}$-value of the polyion assembly and number of the reaction cycles may be attributed to the increase in the size of the $\mathrm{ZnS}$ nanocrystallites in the polyion matrix.

However, with the decreasing particle size of the $\mathrm{ZnS}$ particles in the polyion matrix, due to a large surface-to-volume ratio, the increase in the surface state density promotes the non-radiative recombination, which reflects in the emission at energy lower than the band gap of the material. Consequently, the increase in the blue emission intensity is obtained, whereas the band-to-band emission intensity is reduced as observed from the PL spectra in the Figure 8 . In solids, there is a tendency for a certain type of defect to arise due to different energy of their formation. For the $\mathrm{ZnS}$ nanoparticles the emission wavelength below $430 \mathrm{~nm}$ has been reported for the transitions involving interstitial states [34]. Since the excess of sulfur ions was present for the $\mathrm{ZnS}$ formation within polyion matrix, the emission at $410 \mathrm{~nm}$ may be assigned to the transitions arising from the interstitial states of sulfur atoms. Furthermore, the blue-shift of the surface state emission wavelength can be explained by a simultaneous increase in the energy separation of the charge carriers within the band gap, caused by reduction in the average size of the nanoparticles [35]. 
3.2. Crystalline $\mathrm{TiO}_{2}$ film synthesis with the In-situ sol gel reaction in $\mathrm{PEM}_{\mathrm{S}}$

\subsubsection{Film thicknesses}

The in-situ sol gel reaction of Ti-isopropoxide anhydrous precursor was initiated within the PEM template assembled of 7, 12 and 17 PE bilayers (see experimental).

After the infiltration of the precursor in the PEM template a linear increase in the PEM-TiO hybrid film thickness is observed with increasing the number of the adsorbed PE bilayers in PEM as shown in the Figure 9.

The profilometry thickness measurements of the PEM multilayer, $\mathrm{TiO}_{2} / \mathrm{PEM}$ hybrid and nanocrystalline $\mathrm{TiO}_{2}$ films are shown in the Table 2 .

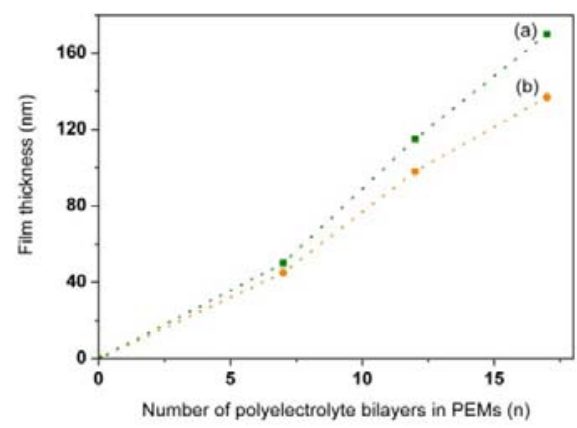

Figure 9. A plot of (a) the thickness of the $\mathrm{TiO}_{2}$ /organic hybrid film and (b) the thickness of the crystalline $\mathrm{TiO}_{2}$ film versus the number of PE bilayers in the PEM template.

Table 2. Thickness values of PEM multilayer, $\mathrm{TiO}_{2} / \mathrm{PEM}$ hybrid and nanocrystalline $\mathrm{TiO}_{2}$ films.

\begin{tabular}{|c|c|c|c|c|}
\hline $\begin{array}{c}\text { Number of PE } \\
\text { bilayers in the } \\
\text { PEM template }\end{array}$ & $\begin{array}{c}\text { PEM template } \\
\text { thickness } \\
(\mathrm{nm})\end{array}$ & $\begin{array}{c}\mathrm{TiO}_{2} / \mathrm{PEM} \text { hybrid } \\
\text { film thickness } \\
(\mathrm{nm})\end{array}$ & $\begin{array}{c}\text { Crystalline } \mathrm{TiO}_{2} \\
\text { film thickness } \\
(\mathrm{nm})\end{array}$ & $\begin{array}{c}\text { Shrinkage in the } \\
\text { film thickness after } \\
\text { calcinations } \\
(\%)\end{array}$ \\
\hline 7 & 50 & 52 & 45 & 13 \\
\hline 12 & 113 & 115 & 98 & 15 \\
\hline 17 & 168 & 170 & 140 & 19 \\
\hline
\end{tabular}

The average incremental thickness of $10 \mathrm{~nm}$ per PE layer, calculated from 5 PE bilayers up, in the multilayer template is observed for PEM assembled at $\mathrm{pH}$-value of 3.0.

By exposing the PEM to the titanium iso-propoxide precursor, the precursor infiltrates the PEM template. When compared to the PEM template thickness, there is hardly any difference observed in the thickness of the $\mathrm{TiO}_{2} / \mathrm{PEM}$ film, which points to the uniform dispersion of the precursor within the PEM matrix. Due to incorporated carboxylic groups within the PEM template, the primary interaction expected is the metal-carboxylate formation [36-37]. The metal-oxo carboxylates have the capability of forming covalent bonds between the inorganic and organic phases. Thereby, within the PEM multilayers homogeneous inorganic-organic network is formed, whereas the thickness of the hybrid film is defined by the PEM template thickness. During the annealing process, the organic component of the $\mathrm{TiO}_{2}$ hybrid coating is gradually removed from the inorganic/organic hybrid film, causing the formation of a dense and compact film, composed of the $\mathrm{TiO}_{2}$ crystallites. As a result, the shrinkage in the film thickness is obtained, as shown in the Figure 10. The film thicknesses before and after the annealing are displayed in Table 3.

Furthermore, the measured thicknesses of the crystalline $\mathrm{TiO}_{2}$ films indicate that each PE bilayer contributes an average thickness of $6 \mathrm{~nm}$ to $8 \mathrm{~nm}$ to the final thickness of the $\mathrm{TiO}_{2}$ films. Thus, the in-situ sol-gel process for the formation of the $\mathrm{TiO}_{2}$ film enables the control over the $\mathrm{TiO}_{2}$ film thickness on the nanometer scale by means of varying the number of PE layers in the organic template.

\subsubsection{Surface morphology of the $\mathrm{TiO}_{2}$ films}

In the Figure 10 the surface microstructures $(a, b, c)$ of the $\mathrm{TiO}_{2}$ films fabricated in the PEM templates of 7, 12 and 17 PE bilayers, and a cross-sectional microstructure (d) of the $\mathrm{TiO}_{2}$ film fabricated within a 17-bilayer PEM template are shown. 

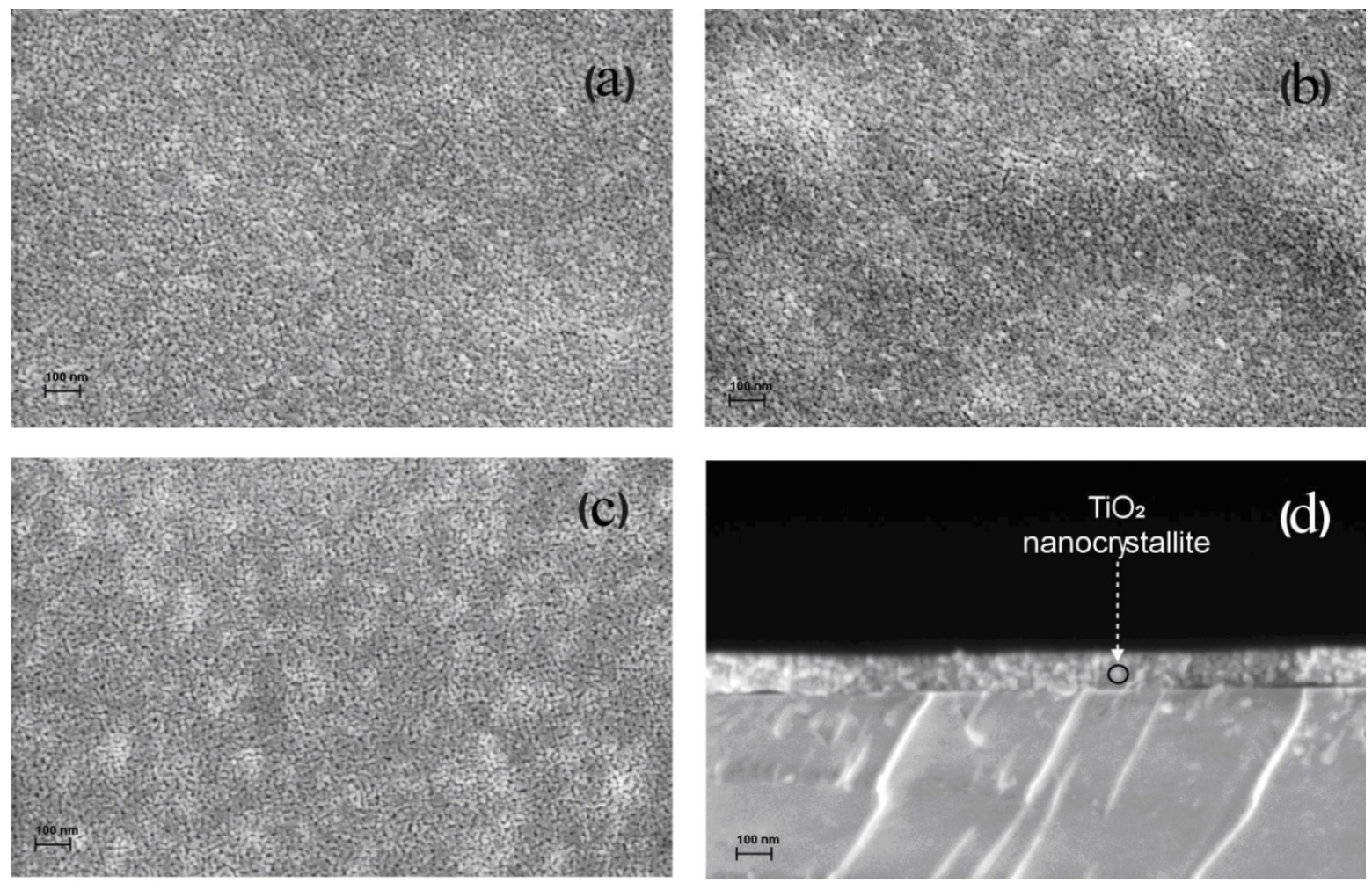

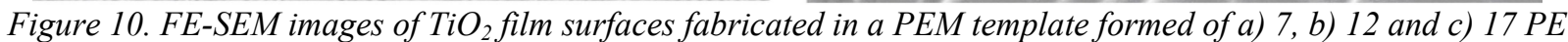
bilayers and d) a cross-section of a TiO film fabricated within a PEM composed of 17 PE bilayers.

Regardless of the thickness of the PEM template, after annealing, nano-crystalline $\mathrm{TiO}_{2}$ films with uniform and relatively dense structures were obtained. The films are formed of the monodispersed $\mathrm{TiO}_{2}$ crystallites, whereas the average $\mathrm{TiO}_{2}$ crystallite size below $15 \mathrm{~nm}$ is obtained. Due to the extreme sensitivity of titanium iso-propoxide to water, high reaction rates of hydrolysis and condensation in the sol-gel process normally result in large, polydispersed particles yielding high surface roughness of the $\mathrm{TiO}_{2}$ film [38].

Within the PEMs matrix, titanium iso-propoxide reacts with organic carboxylic acid thus forming metal acylates with a release of alcohol, whereas carboxylate groups may coordinate to the titanium atom in three possible structures [39]. The carboxylate can bind either to one $\mathrm{Ti}^{\mathrm{IV}}$ center resulting in a bidentate or monodentate mode or it can bind with each of its oxygen atoms to two $\mathrm{Ti}^{\mathrm{iV}}$ centers yielding the bridging bidendate mode. By this, carboxylate ligands slow down the rates of hydrolysis and condensation reactions of the precursor with water absorbed in PEM, yielding $\mathrm{TiO}_{2}$ cluster formation that are sterically stabilized by the surrounding organic ligands, which prevents aggregation and further growth of the $\mathrm{TiO}_{2}$ particles formed within the PEM template.
Furthermore, by heating up to $350^{\circ} \mathrm{C}$, the amidization reaction occurs between the electrostatically binded carboxylate groups of PAA and the ammonium groups of PAH in the PEM which leads to the formation of nylon-like cross-links within the multilayer film. ${ }^{39}$ Thereby, during the annealing process, the rigid polymer matrix limits the particle growth thus enabling the formation of uniform, nanocrystalline $\mathrm{TiO}_{2}$ films.

Figure 11 shows the X-ray diffraction pattern of the $\mathrm{TiO}_{2}$ films formed in the PEM template and sintered at $500^{\circ} \mathrm{C}$ for 1 hour. According to the X-ray diffraction, the thus-prepared $\mathrm{TiO}_{2}$ films had a pure anatase crystal structure.

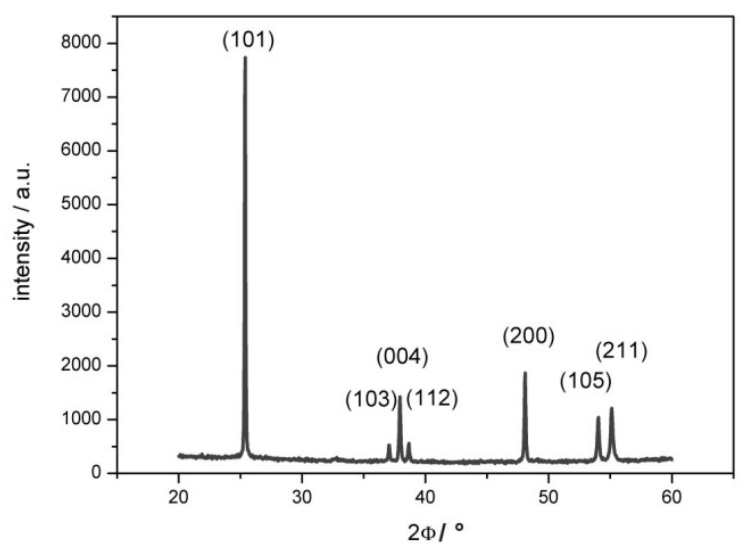

Figure 11. X-ray diffraction pattern of the $\mathrm{TiO}_{2}$ films. 


\subsubsection{Surface roughness of the $\mathrm{TiO}_{2}$ films}

The $\mathrm{TiO}_{2}$ film roughness evaluated using an atomic force microscope (AFM) is shown in Figure 12. The root mean square (RMS) surface roughness of the $\mathrm{TiO}_{2}$ films was measured over an area of $10 \mathrm{x}$ $10 \mu \mathrm{m}^{2}$. The RMS values of the $\mathrm{TiO}_{2}$ film fabricated within the templates composed of 7,12 and $17 \mathrm{PE}$ bilayers were $3.2 \mathrm{~nm}, 7.3 \mathrm{~nm}$ and $9.2 \mathrm{~nm}$, respectively.

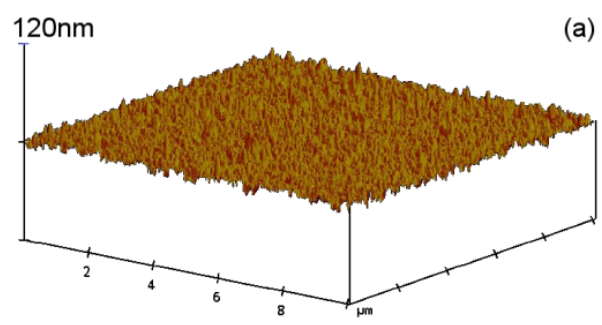

(b)

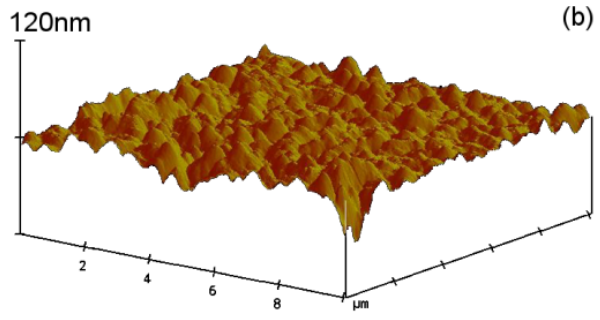

(c)

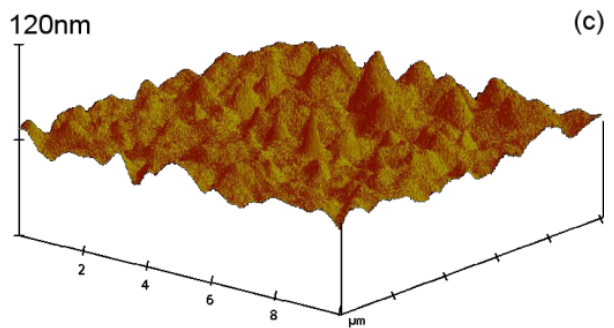

Figure 12. AFM images of $\mathrm{TiO}_{2}$ films fabricated in a PEM template formed of a) 7, b) 12 and c) $17 \mathrm{PE}$ bilayers.

The very low roughness of the films confirms the uniform and homogeneous surface of the $\mathrm{TiO}_{2}$ films fabricated with the in-situ sol-gel reaction within the PEM template. It is attributed to the formation of fine $\mathrm{TiO}_{2}$ particles, due to controlled sol-gel reaction rates and stabilization of the $\mathrm{TiO}_{2}$ particles by the surrounding polymer template. However, an increase in the surface roughness of the $\mathrm{TiO}_{2}$ film is observed as the number of PE bilayers is increased from 7 to 17 . As the thickness of the multilayer template is increased, more of the precursor solution is infiltrated in the PEM, which leads to reduce steric stabilization of the $\mathrm{TiO}_{2}$ clusters by the surrounding polymer chains. Consequently, a more extended aggregation of the $\mathrm{TiO}_{2}$ clusters in the hybrid film results in the increase in the particle size.

\subsubsection{Optical properties of $\mathrm{TiO}_{2}$ films}

UV-vis spectroscopy was used to characterize the optical properties of the $\mathrm{TiO}_{2}$ films fabricated within the organic template composed of 7,12 and 17 PE bilayers. From the absorption spectra in the Figure 13, a blue-shift of $40 \mathrm{~nm}$, compared to the $\lambda_{\max }$ of the bulk anatase $\mathrm{TiO}_{2}$, is observed.

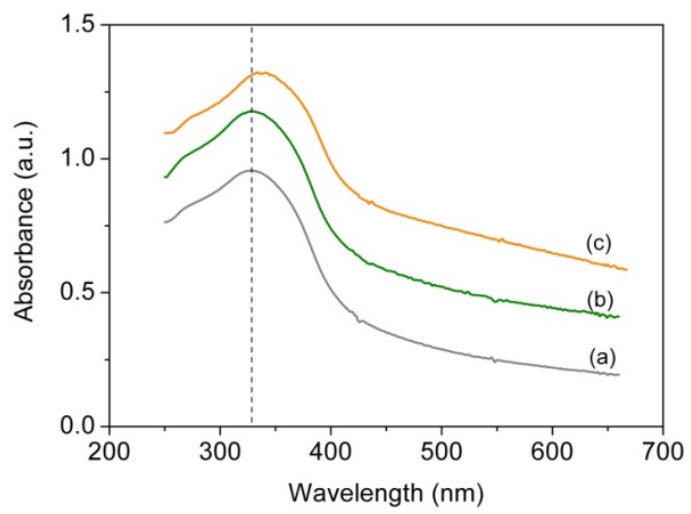

Figure 13. UV-vis absorption spectra of $\mathrm{TiO}_{2}$ films fabricated within (a) 7, (b) 12 and (c) 17 PE bilayered templates.

$\mathrm{TiO}_{2}$ is a wide-band-gap oxide semiconductor with an optical band gap of $385 \mathrm{~nm}(3.2 \mathrm{eV})$ for the anatase crystal structure. While a blue-shift in the absorption wavelength of $85 \mathrm{~nm}$ corresponds to a crystallite diameter of 3 to $5 \mathrm{~nm}$ [40], the blue-shift of $40 \mathrm{~nm}$ in the absorption maxima of the $\mathrm{TiO}_{2}$ films from the absorption spectra in the Figure 14 supports the observations from the FE-SEM images that the $\mathrm{TiO}_{2}$ crystallite size is about $10 \mathrm{~nm}$.

By increasing the number of PE bilayers of the template from 7 to 17 , the $\mathrm{TiO}_{2}$ film thicknesses increased from 45 to $130 \mathrm{~nm}$. With the increasing thickness of the fi! $m$, larger $\mathrm{TiO}_{2}$ crystallites were observed in the film, and hence the $\mathrm{TiO}_{2}$ film had a greater roughness, whereas the absorption edge is red shifted. Therefore, as previously reported, an increase in the crystallite diameter, the thickness increment and the higher roughness of the $\mathrm{TiO}_{2}$ films could be responsible for the red shift of the absorptionmaxima peak position as the number of PE bilayers in the organic template is increased from 7 to 17 [41-42].

A general expression in semiconductor physics that relates the absorption coefficient to the energy band gap is $(\alpha h v)=A_{i}\left(h v-E_{g}\right)^{m}$, where $m$ is the integer or semi-integer, $h$ is the Planck constant, $h v$ is the energy of the electromagnetic radiation and $E_{g}$ is the energy of the involved quantum levels in the semiconductor. When $\mathrm{m}=2$ the transitions of the electrons from the valence to the conduction band are indirectly allowed, while when $\mathrm{m}=1 / 2$ under 
electromagnetic excitation electron transitions in semiconductor are directly allowed [43-44]. To determine the type of band-to-band transition in the $\mathrm{TiO}_{2}$ nano-crystallites in the films, the absorption data were fitted to the equations of indirect and direct band-gap transitions.

In the Figure 14 a plot of $(\alpha h v)^{1 / 2}$ versus $h v$ is shown, which is used to calculate the energy bandgap, considering the indirectly allowed transitions of $\mathrm{TiO}_{2}$ films.

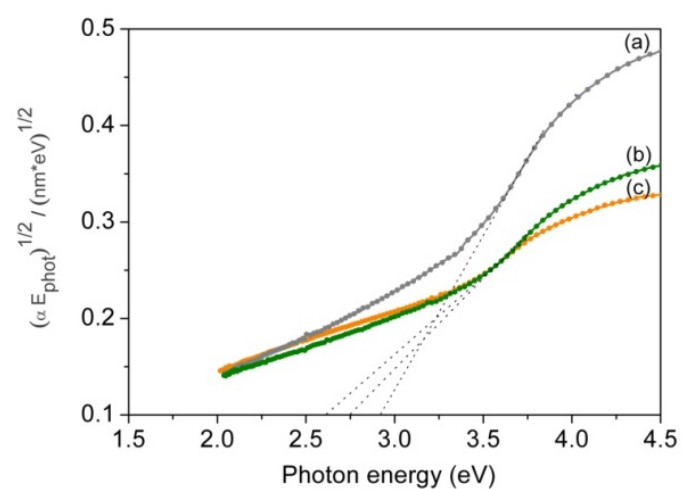

Figure 14. A plot of $\alpha^{1 / 2}$ versus $E_{\text {phot }}$ for an indirect transition Bandgap energies $\left(E_{g}\right)$ are obtained by extrapolation to $\alpha=0 ; \mathrm{TiO}_{2}$ formed within the (a) 7, (b) 12 and (c) 17 bilayered PEM template.

For a quantitative evaluation of the band-gap energy, an extrapolation of the absorption edge to $\alpha=0$ is required [45]. The calculated values of the band-gap energies for the $\mathrm{TiO}_{2}$ films formed in templates fabricated from 7,12 and $17 \mathrm{PE}$ bilayers are $2.95 \mathrm{eV}, 2.75 \mathrm{eV}$ and $2.62 \mathrm{eV}$, respectively. The extrapolated values of the band-gap energies from the plots of the indirect transition are lower than the band-gap energy of the bulk anatase $\mathrm{TiO}_{2}$, which contradicts the quantum-confinement effect known for $\mathrm{TiO}_{2}$ crystallite diameters of less than $15 \mathrm{~nm}$, due to which, the band-gap energy should be higher than $3.2 \mathrm{eV}$ [46]. Therefore, the data were adjusted to the direct-band-gap relation.

In the Figure 15 a plot of $(\alpha h v)^{2}$ versus $h v$ for the directly allowed transitions is shown.

The values of the band-gap energies estimated from an $\alpha=0$ extrapolation for the samples formed in the 7,12 and $17 \mathrm{PE}$ bilayered templates are 3.47 $\mathrm{eV}, 3.3 \mathrm{eV}$ and $3.25 \mathrm{eV}$, respectively. The obtained values of the energy gap are in accordance with the previous results for direct-band-gap of anatase $\mathrm{TiO}_{2}$ nanoparticles [40]. The extrapolated values of the band-gap energies in Figure 52 also show a decrease in the band-gap energy for the directly allowed transitions from $3.47 \mathrm{eV}$ to $3.25 \mathrm{eV}$ as the $\mathrm{TiO}_{2}$ film thickness is increased from 45 to $130 \mathrm{~nm}$. Since a similar trend of decreasing the band-gap energy with in- creasing the PEM template thickness is observed in the case of direct and indirect transitions, due to the quantum-confinement effect, the blue-shift of the band-gap energy indicates an increase in the $\mathrm{TiO}_{2}$ crystallite size with the increasing $\mathrm{TiO}_{2}$ film thickness [41]. Since the average crystallite diameter about $10 \mathrm{~nm}$ in the $\mathrm{TiO}_{2}$ film formed in the template of $17 \mathrm{PE}$ bilayers is observed, the increase in the band-gap energy with decreasing the film thickness points to a decrease in the crystallite size below 10 $\mathrm{nm}$ as the $\mathrm{TiO}_{2}$ films are formed in the templates composed of lower number of PE bilayers. Although in bulk $\mathrm{TiO}_{2}$, only indirect electron transitions are allowed, it is possible that direct electron transitions in crystallites of $\mathrm{TiO}_{2}$ films are more favorable due to a reduced size and surface effects of the $\mathrm{TiO}_{2}$ nanocrystallites as the size of the particles approaches the quantum confinement regime. The electronic transitions for direct semiconductors are electrical-dipole assisted, while, for the indirect semiconductors, the electron transition from the valence to the conduction band is phonon assisted and, since they involve a change in momentum, their absorption and emission are weaker, compared to those of direct-bandgap semiconductors [47]. Therefore, due to favorable direct electron transitions, $\mathrm{TiO}_{2}$ films fabricated with the in-situ sol-gel reaction within the PEM template exhibit a more efficient energy absorption.

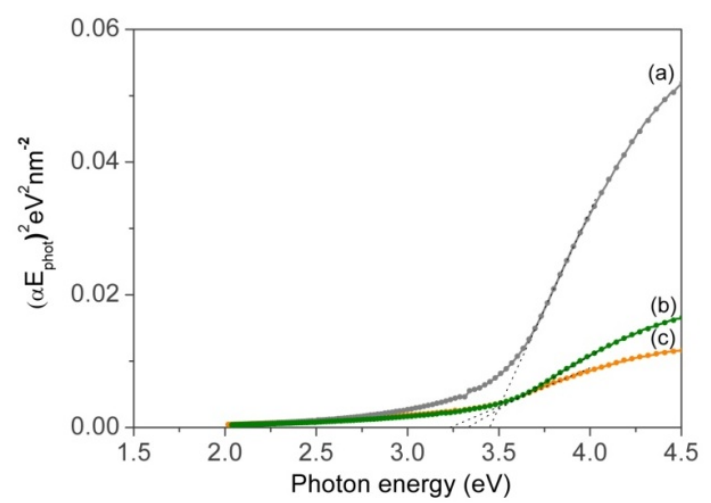

Figure 15. A plot of $\left(\alpha E_{\text {phot }}\right)^{2}$ versus $E_{\text {phot }}$ for direct transition. Bandgap energies $\left(E_{g}\right)$ are obtained by extrapolation to $\alpha=0$. $\mathrm{TiO}_{2}$ formed within the (a) 7, (b) 12 and (c) 17 bilayered PEM template.

In the Figure 16, the transmission of visible light $\mathrm{TiO}_{2}$ films synthesized in the template formed of 7,12 and $17 \mathrm{PE}$ bilayers is shown.

$\mathrm{TiO}_{2}$ films fabricated in the template formed of 7, 12 and 17 PE bilayers are highly transparent in the visible region of the electromagnetic spectrum (Figure 16). The highest visible-light transparency of $80 \%$ was observed for the $\mathrm{TiO}_{2}$ film fabricated in the multilayer template composed of 7 PE bilayers; with a larger number of PE bilayers in the organic tem- 
plate, a reduced transmission of crystalline $\mathrm{TiO}_{2}$ film was obtained.

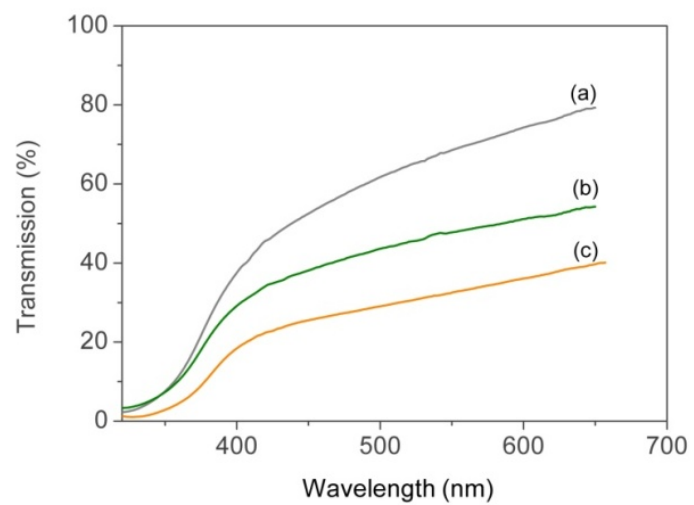

Figure 16. Transmission spectra of $\mathrm{TiO}_{2}$ films fabricated within the multilayer template composed of a) 7, b) 12 and c) 17 PE bilayers.

The increase in the $\mathrm{TiO}_{2}$ film thickness and surface roughness yields lower transmission of visible light [48]. Since an increase in the template thickness leads to a simultaneous increase in the crystalline $\mathrm{TiO}_{2}$ film thickness and film roughness, these factors could be the reason for a reduced transmission of visible light of the $\mathrm{TiO}_{2}$ films as the number of the PE bilayers in the template is increased from 7 to 17 .

\section{CONCLUSION}

Homogeneous inorganic-organic nanostructured composite and inorganic crystalline films were formed by the in-situ synthesis of $\mathrm{ZnS}$ nanoparticles and in-situ sol-gel reaction in the weak polyion assemblies. We have demonstrated that spatially selective nucleation and growth of the spherical $\mathrm{ZnS}$ nanocrystal within the weak polyion matrix is obtained by complexation of metal ions to the carboxylic groups of the weak polyacid chains in the multilayer followed by subsequent precipitation reaction. The $\mathrm{pH}$-controlled supramolecular organization of the weak polyions induces the formation of voids wherein aggregative growth mechanism of the primary nanoparticles yields the formation of spherical $\mathrm{ZnS}$ nanoparticles. The difference in size and volume density of $\mathrm{ZnS}$ nanocrystals in PEM, induced by the variation in the $\mathrm{pH}$-value of the polyion assembly, indicates that conformational arrangement of polyion chains and concentration of the carboxylic groups in the multilayer film are the key parameters influencing the growth mechanism of $\mathrm{ZnS}$ nanocrystals in the weak polyion matrix. Furthermore, the increase in the size and volume fraction of $\mathrm{ZnS}$ nanocrystallites in PEM is also obtained by cycling the absorption-precipititation reaction process, where the Ostwald ripening may be the dominant growth mechanism. On the other hand, nanocrystalline anatase $\mathrm{TiO}_{2}$ films with controlled thicknesses were fabricated by using a modified sol-gel method within a PEM template, fabricated by the LbL self-assembly of appositively charged polyelectrolytes. By controlling the thickness of the PEM template, the control over the crystallite size, the surface morphology and the surface roughness of the $\mathrm{TiO}_{2}$ films was obtained. Regardless of the template thickness, an average crystallite size of about $10 \mathrm{~nm}$ was observed in the final $\mathrm{TiO}_{2}$ films. With the ability of obtaining the control over the size, size distribution and surface states, the density of the $\mathrm{ZnS}$ nanoparticles, attributed to the surface passivation of the $\mathrm{ZnS}$ nanoparticles by the polyion matrix, tunability of optical absorption and emission properties of the inorganic/organic nanostructured composite films is obtained. Large-surface-area nanostructured $\mathrm{TiO}_{2}$ films show strong absorption in the UV region and high transparency in the visible region of the electromagnetic spectra. Moreover, the direct allowed electron transitions and control over the crystallite size of the $\mathrm{TiO}_{2}$ films result in an enhanced absorption that could, in turn, enable their use for enhanced optical and photo-catalytic applications.

\section{REFERENCES}

[1] A. Heilmann, Polymer Films with Embedded Metal Nanoparticles, 2002

[2] R. S. Kane, R. E. Cohen, R. Silbey, Langmuir, 15,1,1999

[3] R. Bhargava, Properties of Wide Bandgap II-VI Semiconductors, 1997

[4] G. Decher, J. D. Hong, J. Schmitt, Thin solid films, 210/211, 831

[5] S. Dante, Z. Hou, S. Risbud, P. Stroeve, Langmuir, 15,2176, 1999

[6] A. K. Dutta, G. Jarero, L. Zhang, P. Stroeve, Chem. Mater. 12, 176, 2000

[7] S. Joly, R. Kane, L. Radzilowski, T. Wang, A. Wu, R. E. Cohen, E.L. Thomas, M. F. Rubner, Langmuir, 16,1354,2000

[8] M. Logar, B. Jančar, D. Suvorov, R. Kostanjšek, Nanotechnology 18, 325601, 2007

[9] M. Grätzel, Chemistry, Conversion of sunlight to electric power by nanocrystalline dye-sensitized solar cells, J. Photochem.Photobiol. A, 164 3(2004).

[10] A. Rothschild, F. Edelman, Y. Komem, F. Coasadey, Sensing behavior of TiO thin films ex- 
posed to air at low temperatures, Sens. Actuators B: Chemical, 67282 (2000).

[11] Hsuan-Fu Yu, Fa-Chun $\mathrm{Hu}$, Preparation and characterization of transparent $\mathrm{TiO}_{2}$ thin films coated on fused-silica substrates, J Sol-Gel Sci Technol., 52158 (2009).

[12] S. Mo, W. Ching, Electronic and optical properties of three phases of titania dioxide: Rutile, anatase, and brookite, Phys. Rev.B, 5113023 (1995).

[13] A. Aidla, T. Ustare, A. A.Kiisler, J. Aarik, V. Sammelselg, Thin Solid Films, Effect of crystal structure on optical properties of $\mathrm{TiO}_{2}$ films grown by atomic layer deposition, 305270 (1997).

[14] M. O. Abou-Helal, W. T. Seeber, Preparation of $\mathrm{TiO}_{2}$ thin films by spray pyrolysis to be used as a photocatalyst, Appl. Surf. Sci., 19553 (2002).

[15] Y. Choi, S. Yamamoto, T. Umebayashi, M. Yoshikawa, Fabrication and characterization of anatase $\mathrm{TiO}_{2}$ thin film on glass substrate grown by pulsed laser deposition, Solid State Ionics, 172105 (2004).

[16] L. Hu, T. Yoko, H. Kozuka, Thin Solid Films, Effects of solvent on properties of sol-gelderived $\mathrm{TiO}_{2}$ coating films, 21918 (1992).

[17] P. Chrysicopoulo, D. Davazoglou, C. Trapalis, G. Kordas, Optical properties of very thin $(<100 \mathrm{~nm})$ sol-gel $\mathrm{TiO}_{2}$ films, Thin Solid Films, 323 188 (1998).

[18] Y. Li, J. Hagen, W. Schaffrath, P. Otschik, D. Haarer, Titanium dioxide films for photovoltaic cells derived from a sol-gel process, Sol. Energy Mater. Sol. Cells, 56167 (1999).

[19] K. K. Saini, S. D. Sharma, Chanderkant, K. Meenakshi, D. Singh, C. P. Sharma, Structural and optical properties of $\mathrm{TiO}_{2}$ thin films derived by sol-gel dip coating process, J. of Non-crystalline solids, 3532469 ( 2007).

[20] D. W. Wang, F. Caruso, PolyelectrolyteCoated Colloid Spheres as Templates for Sol-Gel Reactions, Chem. Mater., 141909 (2002).

[21] D. W. Wang, A. Caruso, F. Caruso, Synthesis of Macroporous Titania and Inorganic Composite Materials from Coated Colloidal Spheres - A Novel Route to Tune Pore Morphology, Chem. Mater., 13364 (2001).

[2] D. W. A. Caruso, F. Caruso, Synthesis of Macroporous Titania and Inorganic Composite Materials from Coated Colloidal Spheres - A Novel Route to Tune Pore Morphology, Chem. Mater., 13 364 (2001).

[23] S. Joly, R. Kane, L. Radzilowski, T. Wang, A. Wu, R. E Cohen, E. L. Thomas, M. F.
Rubner, Multilayer nanoreactors for metallic and semiconducting Particles. Langmuir 16, 1354 (2000)

[24] R. Vacassy, S. M. Scholz, J. Dutta, C. J. G. Plummer, R. Houriet, H. Hofmann, Synthesis of controlled spherical zinc sulfide particles by precipitation from homogeneous solutions. J. Am. Cheram.Soc. 81, 2699 (1988)

[25] T. C. Wang, M. F. Rubner, R. E. Cohen, Polyelectrolyte multilayer nanoreactors for preparing silver nanoparticle composites: Controlling metal concentration and nanoparticle size. Langmuir 18,3370 (2002)

[26] K. Manzoor, V. Adotyaq, S. R Vadera, N. Kumar, T. R. N. Kutty, Spontaneous organisation of $\mathrm{ZnS}$ nanoparticles into monocrystalline nanorods with highly enhanced dopant-related emission. J.Phys.Chem.Solids 66, 1164 (2005)

[27] R. L. Penn, J. F. Banfield, Imperfect oriented attachment: a mechanism for dislocation generation in defect-free nanocrystals. Science 281, 969 (1998)

[28] R. L. Penn, G. Oskam, G. J. Sterathmann, P. C. Searson, A. T. Stone, D. R. Veblen, Epitaxial Assembly in Aged Colloids. J. Phys.Chem. B 105, 2177 (2001)

[29] F. Huang, Z.Hengzhong, J. F. Banfield, Two-stage crystal-growth kinetics observed during hydrothermal coarsening of nanocrystalline $\mathrm{ZnS}$. Nano Lett.3, 373 (2003)

[30] J. F. Banfield, S. A. Welch, H. Zhang, T. T. Ebert, R. L. Penn, Aggregation-based crystal growth and microstructure development in natural iron oxyhydroxide biomineralization products. Science 289, 751 (2000)

[31] K. Dutta, S. Manna, S. K. De, Optical and electrical characterizations of $\mathrm{ZnS}$ nanoparticles embedded in conducting polymer. Synth. Met. 159, 315 (2009)

[32] Y. Wang, N. Herron, Nanometer-sized semiconductor clusters: materials synthesis, quantum size effects, and photophysical properties. J. Phys. Chem., 95, 525 (1991)

[33] N. Kumbhojkar, V. V. Nikesh, A. Kshirsagar, Photophysical properties of ZnS nanoclusters. J. App. Phys., 88, 6260 (2000)

[34] D. Denzler, M. Olschewski, K. Sattler, Luminescence studies of localized gap states in colloidal ZnS nanocrystals. J. App. Phys. 84, 2841 (1998)

[35] B. Bhattacharjee, D. Ganduli, S. Chaudhuri, Growth Behavior of CdS Nanoparticles Embedded in Polymer and Sol-Gel Silica Matrices: Relationship with Surface-State Related Luminescence. J. of Fluorescence 12, 369 (2002) 
[36] C. R. Wold, H. Ni, M. D. Soucek, Model reaction study on the interaction between the inorganic and organic phases in drying oil based ceramer coatings. Chem. Mater., 13, 3032 (2001)

[37] E. A. Barringer, H. K. Bowen, High-purity, monodisperse $\mathrm{TiO}_{2}$ powders by hydrolysis of titanium tetraethoxide. 1. Synthesis and physical properties. Langmuir, 1, 414 (1985)

[38] F. P. Rotzinger, J. M. Kessekman-Truttmann, S. J. Hug, V. J. Shklover, M. Graetzel, Structure and vibrational spectrum of formate and acetate adsorbed from aqueous solution onto the $\mathrm{TiO}_{2}$ rutile (110) surface. Phys. Chem.B, 108, 5004 (2004)

[39] J. D. Mendelsohn, C. J. Barrett, V. V. Chan, A. J. Pal, A. M. Mayes, M. F. Rubner, Fabrication of microporous thin films from polyelectrolyte multilayers. Langmuir 16, 5017 (2000)

[40] S. Monticone, R. Tufeu, A. Kanaev, E. Scolan, C. Sanchez, Influence of deposition conditions on the structural characteristics of sublimated CdTe thin films. App. Surf. Sci., 162/163, 565 (2000)
[41] J. Kim, S. Fujita, Shiratori, S. Fabrication and characterization of $\mathrm{TiO}_{2}$ thin film prepared by a layer-by-layer self-assembly method. Thin solid films, 499, 83 (2006)

[42] T. Dittrich, Porous $\mathrm{TiO}_{2}$ : Electron transport and application to dye sensitized injection solar cells. Phys. Stat. sol. (a), 182, 447 (2000)

[43] A. E. J. Gonzalez, S. G. Santiago, Structural and optoelectronic characterization of $\mathrm{TiO}_{2}$ films prepared using the sol-gel technique. Semicond. Sci. technology, 22, 709 (2007)

[44] O. Madelung, B. C. Taylor, Introduction to Solid State theory (Springer-Verlag, Berlin, 1978)

[45] R. A. Smith, Semiconductors (Cambridge University press, Cambridge, 1978)

[46] L. Ge, M. Xu, M. Sun, H. Fang, Influence of calcination ambient and film thickness on the optical and structural properties of sol-gel $\mathrm{TiO}_{2}$ thin films. Mat. Res. Bull. 41, 1596 (2006)

[47] P. K. Khanna, N. Singh, S. Charan, Synthesis of nano-particles of anatase- $\mathrm{TiO}_{2}$ and preparation of its optically transparent film in PVA. Materials letters, 61, 4725 (2007)

$\operatorname{son}$

\section{ИН-СИТУ СИНТЕЗА НЕОРГАНСКИХ НАНОСТРУКТУРА ПОТПОМОГНУТА ПОЛИЕЛЕКТРОЛИТСКИМ ВИШЕСЛОЈНИМ ШАБЛОНОМ}

Сажетак: Вишеструки слојеви формирани од слабих полијона полиалиламина (ПАХ) и полиакрилне киселине (ПАА), који посједују јон-размјењиве карбоксилне групе коришћени су за везивање катјона у танком филму. Накнадним процесом влажне хемијске реакције инкорпорираних металних јона, у ПЕМ-у су добијене наночестице чистог цинк-сулфида $(\mathrm{ZnS})$, цинк-сулфида и сребра $(\mathrm{Ag})$ допираним манганом са уским распоредом. Величина и концентрација неорганских наночестица у полијонској матрици контролисани су концентрацијом метал-везујућих група карбоксилне киселине што је одређено $\mathrm{pH}$ вриједношћу вишеслојног споја. Надаље, било је могуће у више наврата понављати методологију пуњења и реакције катјона како би се повећала величина и запреминска густина наночестица. Такође су коришћени полиелектролитски вишеслојни филмови као шаблони за израду керамичких $\left(\mathrm{TiO}_{2}\right)$ танких филмова са модификованом сол-гел реакцијом. Будући да се вишеслојни спој изводи из полијонских водених раствора, вишеструки слојеви садрже нешто воде која након инфилтрације органометалског претходника омогућава ин-ситу реакције хидролизе и кондензације. Након калцинације формирани су нанокристални танки филмови $\mathrm{TiO}_{2}$ дебљине, што је могуће контролисати на основу неколико полијонских слојева у матрици.

С приступом ин-ситу синтезе неорганских наноструктура у полиелектролитској вишеслојној матрици, могућност добијања контроле над дебљином филма и величином неорганских честица омогућила је подешавање оптичких својстава као израђених неорганско-органских композитних филмова као и нанокристалних керамичких филмова.

Кључне ријечи: вишеслојни полиелектролити, ин-ситу синтеза, ZnS наночестице, нанокристални $\mathrm{TiO}_{2}$ филм. 